\title{
Re-Use of Silico-Manganese Slag
}

\author{
Daniela Laura Buruiana ${ }^{1} \mathbb{D}$, Cristian-Dragos Obreja ${ }^{2}$, Elena Emanuela Herbei ${ }^{1}(\mathbb{D})$ and Viorica Ghisman ${ }^{1, * \mathbb{D}}$ \\ 1 Interdisciplinary Research Centre in the Field of Eco-Nano Technology and Advance Materials CC-ITI, \\ Faculty of Engineering, "Dunarea de Jos” University of Galati, 47 Domneasca, 800008 Galati, Romania; \\ daniela.buruiana@ugal.ro (D.L.B.); elena.valcu@ugal.ro (E.E.H.) \\ 2 Department of Materials and Environmental Engineering, Faculty of Engineering, "Dunarea de Jos" \\ University of Galati, 47 Domneasca, 800008 Galati, Romania; Cristian.obreja@ugal.ro \\ * Correspondence: viorica.ghisman@ugal.ro
}

Citation: Buruiana, D.L.; Obreja, C.-D.; Herbei, E.E.; Ghisman, V. Re-Use of Silico-Manganese Slag. Sustainability 2021, 13, 11771. https://doi.org/10.3390/su132111771

Academic Editor:

Jorge Rodríguez-Chueca

Received: 7 September 2021

Accepted: 21 October 2021

Published: 25 October 2021

Publisher's Note: MDPI stays neutral with regard to jurisdictional claims in published maps and institutional affiliations.

Copyright: (c) 2021 by the authors. Licensee MDPI, Basel, Switzerland. This article is an open access article distributed under the terms and conditions of the Creative Commons Attribution (CC BY) license (https:// creativecommons.org/licenses/by/ $4.0 /)$.

\begin{abstract}
The world's rapidly growing demand for raw manganese has made it increasingly important to develop methods for the economic recovery of manganese from secondary sources. The current study aims to present possible ways for the recycling and reuse of silico-manganese slag landfilled in Tulcea, City on the Danube River close to the Danube Delta Biosphere Reserve in order to save the natural resources raw of manganese. In the last three decades, the ferroalloy production plant has over 2.6 million tons of slag. Slag dumping constitutes a significant source of air, water and soil pollution, which adversely affects the environment and human health. Mn present in the slag dump is an environmental pollutant with potentially toxic effects. The results obtained with a leaching method to recover manganese from slag shows two efficient ways to valorize manganese from solid fraction (54\%) with size particles between 80 and $315 \mu \mathrm{m}$ and/or reuse the leaching medium $(56 \% \mathrm{Mn})$ with a slag size of $<80 \mu \mathrm{m}$. The motivation of our research is the possibility to recover manganese from slag by saving natural resources of raw of manganese and the remaining fraction can be used as aggregate sources (construction and road rehabilitation by saving extract mineral aggregates and agriculture), in order to decommission the slag dump. The proposed research is in concordance with the sustainable use of natural resources for the achievement of sustainable development of the 2030 Agenda and Waste Management Legislation due of the huge ecological costs regarding non-conforming waste dumping. If we consider the cost-benefit analysis, the environmental future is more important the human health and the benefits on the quality of the population's health and the environment which are not non-measurable in monetary value.
\end{abstract}

Keywords: manganese; silico-manganese slag; toxic metals; pollution risk; leaching method

\section{Introduction}

One of the major problems today in the steel industry is the production of large amounts of waste. Waste solids that emerge from steel plants are in the form of slags, sludges and dust. It is well known that the dust particles can cause cardiovascular and respiratory health problems [1-3]. In steel production the majority of slags generated are blast furnace slag and steel melting slag. A lot of studies have been made on the utilization of blast furnace slag for the concrete and engineering applications. Air-cooled slag and granulated slag are the types of the blast furnace slag generated from steel plants. The application scope for the air-cooled slag is as aggregate in road making processes, and blast furnace granulated slag is as additive in the production of cement [4]. Steel slag, discharged at a high temperature range, is a by-product of the steelmaking and steel refining processes. During the production of steel, one ton of slag waste is generated per every three tons of stainless steel produced [5]. In the past, the main way to deal with steel slag waste was to dump in landfill sites, which gave rise to serious environment pollution [6]. The program HORIZON 2020 of the EU is to support the ecologically friendly economy, and one of the priorities is to recover and recycle resources from metallurgical wastes [7-9]. 
A contribution to increase global sustainability is the consumption and reuse of a large volume of slag waste dumped in landfill sites [10]. Nowadays, the general environmental topics are saving the natural river aggregates and global warming [11]. A significant source of air, water and soil pollution which adversely affects the environment and human health is the landfilled with the waste slags [12-15]. In recent years, the reuse of different metallurgical slags has attracted the attention of many researchers. These different slags from ferrous metallurgical industry are blast furnace, steel, stainless steel, ferroalloy slags and so on. In the ferroalloy production, a large amount of slag is produced and mostly is landfilled. Because of the fact that only a small part of ferroalloy slag showed interest in the cement industry, the necessity to find additional ways to reuse the ferroalloy slag is high [16]. Particularly, Tulcea city, southeast of Romania and situated in the lower sector of the Danube River, has a ferroalloy production plant and a shipyard. The main type of slag obtained is silicomanganese ( $\mathrm{SiMn}$ ) slag. The manganese accompanies, in general, the iron in oxides and silicates. Mineral ores for industrial uses are pyrolusite $\left(\mathrm{MnO}_{2}\right)$, psilomelane $\left(\mathrm{K}, \mathrm{Ba} \mathrm{MnO} \mathrm{M}_{2} \cdot \mathrm{H}_{2} \mathrm{O}\right)$, manganite $\left(\mathrm{Mn}_{2} \mathrm{O}_{3} \cdot \mathrm{H}_{2} \mathrm{O}\right)$, braunite $\left(3 \mathrm{MnO}_{3} \cdot \mathrm{MnSiO}_{3}\right)$ and rhodochrosite $\left(\mathrm{MnCO}_{3}\right)$ [17]. The manganese ferroalloys such as silicomanganese slag are very important components in steel production because of the advantages of manganese on physical properties of steel. By adding manganese and ferro-manganese in the process of steel metallurgy, it has the role of a de-oxidizer and de-sulphurizer [18]. The reduction of ferromanganese slags to manganese metal in a rotary furnace has been reported [19]. Byung Su Kim et al. [20] recovered about 20\% of the manganese from silicomanganese slag at 6000 Tesla magnetic field by the physical separation method, and their purpose was the utilization as resource of manganese for manufacturing silicomanganese alloy. In other studies, Alexandrov and al. [21] improved the recovery of manganese from slag by using metal melts that contains reducing elements as carbon and silicon. An almost $80 \%$ recovery of manganese from ferromanganese slag was performed by Naganoor et al. [22] using the calcination of the mixed slag with $\mathrm{CaO}$ and $\mathrm{CaCO}_{3}$ and then using a leaching method with ferric chloride in presence of sucrose.

Manganese is essential for important industrial sectors, has no substitutes and the researchers recommend finding ways to extract it from all industries sustain by the Agenda 2030 for Sustainable Development.

The aim of this present research is to obtain manganese in leaching solution by improving of Naganoor et al. method [22] for utilization in the metallurgical processing of steel, such as the Steel Plant of Galati, situated at least $50 \mathrm{~km}$ from the slag dump area [23-25].

It is important to reuse the dumped slag in order to minimize its environmental impact by saving the natural resources of manganese. The purposed method offers economic and environmental benefits to make our community safer [26-28].

The novelty of our research consists in the extraction of manganese from silicomanganese waste slag, especially since the European community sustains the closure of these landfills in accordance with Directive 1999/31/EC, and from an economic point of view, the extraction of the manganese is a priority due to the fact that is an important element in all heavy industries.

\section{Materials and Methods}

\subsection{Area Description and Sampling}

The greatest ferroalloy production from East Europe is located in SE of Romania. The only ferroalloy plant from Romania, with a surface area of 65 ha, has a production of $1000,000 \mathrm{t}$ of ferroalloy/year such as ferroalloy of silicon, manganese, chromium, silicon metal and special ferroalloy, and has provided approximatively $70 \%$ of the needs of Romanian siderurgy. In the last three decades, the ferroalloy production plant has stored for over 2.6 million tons of slag. This deposit is located in Tulcea, the main city of the county of the same name, Dobrogea, Romania, on the shores of Lake Somova and borders the Danube Delta Biosphere Reserve (Figure 1). In 1991, the Danube Delta Biosphere Reserve 
was recognized by UNESCO's Man and Biosphere Program as a wetland of international importance, mainly as a habitat for waterfowl, and since 1999, under the Ramsar Convention, together with the Ukrainian Danube Biosphere Reserve, it was included in the International Network of Transborder Biosphere Reserve.

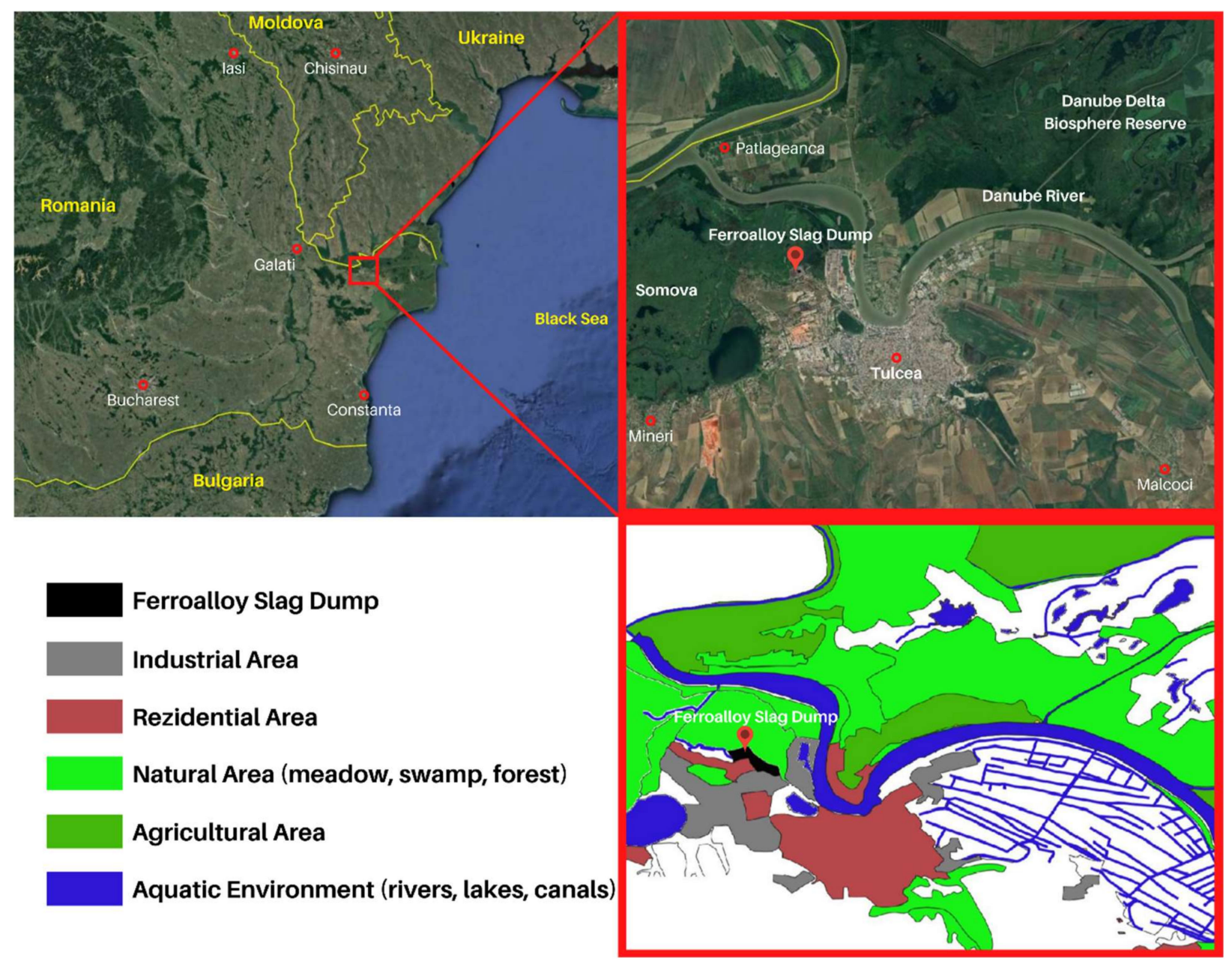

Figure 1. Map of the sampling site location (realized with ArcGIS 10.8 software).

The landfill has been operating since 1976 and large amounts of waste are still landfilled. The climate in Tulcea is temperate continental with sub-Mediterranean influences. The annual average temperature over the last years has been $10.8^{\circ} \mathrm{C}$, and the average annual precipitation about 350 to $500 \mathrm{~mm}$. In Tulcea county, approximately $4000 \mathrm{~h} / \mathrm{year}$ wind speed is higher than $4 \mathrm{~m} / \mathrm{s}$, which favors the dispersion of PM2.5 and PM10 polluting particles [29]. The exposure to air pollutants PM2.5 and PM10 have been associated with a lot of adverse health impacts [30-32].

\subsection{Sample Preparation and Extraction Procedure}

In this research, the investigated silico-manganese slag was collected from ferro-alloy plant of Tulcea, Romania. SiMn slag consists of oxides such as $\mathrm{MnO}, \mathrm{SiO}_{2}, \mathrm{CaO}, \mathrm{Fe}_{2} \mathrm{O}_{3}$, $\mathrm{TiO}_{2}$ and $\mathrm{ZnO}$ and toxic elements such as $\mathrm{Pb}, \mathrm{Cr}$ and As. The slag was coarse in size, and it was crushed and milled in different size fractions. Two series of samples with size fractions of 80 to $315 \mu \mathrm{m}$ and $<80 \mu \mathrm{m}$ were prepared. These samples were used to study the effect of particle size on the leaching efficiency of manganese. To study leaching behavior of ferroalloy slag by ferric chloride, a series of experiments were carried out. Experimental conditions were as follows: $40 \mathrm{~g}$ of powdered silicomanganese slag (80 to $315 \mu \mathrm{m}$ and 
$<80 \mu \mathrm{m}$ ) was mixed with $5 \mathrm{~g}$ of calcium oxide and $5 \mathrm{~g}$ of calcium carbonate and calcinated in a muffle furnace in ceramic tubes for $2 \mathrm{~h}$ at $1474 \mathrm{~K}$.

We consider that the reactions that could took place in furnace at $1474 \mathrm{~K}$ due to the transformation of insoluble $\mathrm{MnOSiO}_{2}$ into soluble $\mathrm{MnO}$ :

$$
\begin{gathered}
\mathrm{MnOSiO}_{2}+\mathrm{CaO} \rightarrow \mathrm{MnO}+\mathrm{CaOSiO}_{2} \\
\mathrm{MnOSiO}_{2}+\mathrm{CaCO}_{3} \rightarrow \mathrm{MnO}+\mathrm{CaOSiO}_{2}+\mathrm{CO}_{2}
\end{gathered}
$$

According to the presented reactions, due to the chemical affinity of the elements support combining of $\mathrm{CaO}$ with $\mathrm{SiO}_{2}$ and could justify the decrease of the melting point of aggregate of $\mathrm{MnOSiO}_{2}$ from $2843 \mathrm{~K}$ to $1523 \mathrm{~K}$.

The resulted calcinated samples were mixed with ferric chloride solution with concentration of $0.1540 \mathrm{M}$. The mixture was carried out in a glass reactor using a magnetic stirrer ( $500 \mathrm{rpm}$ ) at a temperature of $353 \mathrm{~K}$ for $2 \mathrm{~h}$. The leaching solution was obtained by adding a proportion of 1:10 of $1 \mathrm{~N} \mathrm{H}_{2} \mathrm{SO}_{4}$ solution to the roasted sample. The solution was filtered, washed and dried to prelevate the solid part in order to characterize from the elemental composition view.

In this investigation, the effect of particle size of the silico-manganese slag of leaching on the extraction of manganese has been studied.

\subsection{Characterization Techniques}

The SiMn slag waste was characterized by X-ray Fluorescence (XRF) for a quantitative determination of major and trace element concentrations in solid waste material using a calibration with matrix-matched standards.

The morphology and elemental composition of the investigated slag were examined by scanning electron microscopy coupled with energy dispersive X-ray (SEM/EDX) spectroscopy using a FEI Q 200 microscope in low vacuum. Before examination, the samples were coated with 4-nm-thick conducting layer of Au using a SPI-Module ${ }^{\mathrm{TM}}$ sputter coater system.

The SEM images were analyzed with ImageJ software to quantify the shape parameters of the slags. The version 1.46r of ImageJ software can estimate various shape and size determining parameters of slags, e.g., area, mean, standard deviation, mode, etc.

\section{Results and Discussions}

Morphological and Elemental Composition of the Slag

Figure 2 shows the morphology of silicomanganese slag. One can observe from Figure 2 that the SiMn slag studied contains spheres with different granulation fractions.
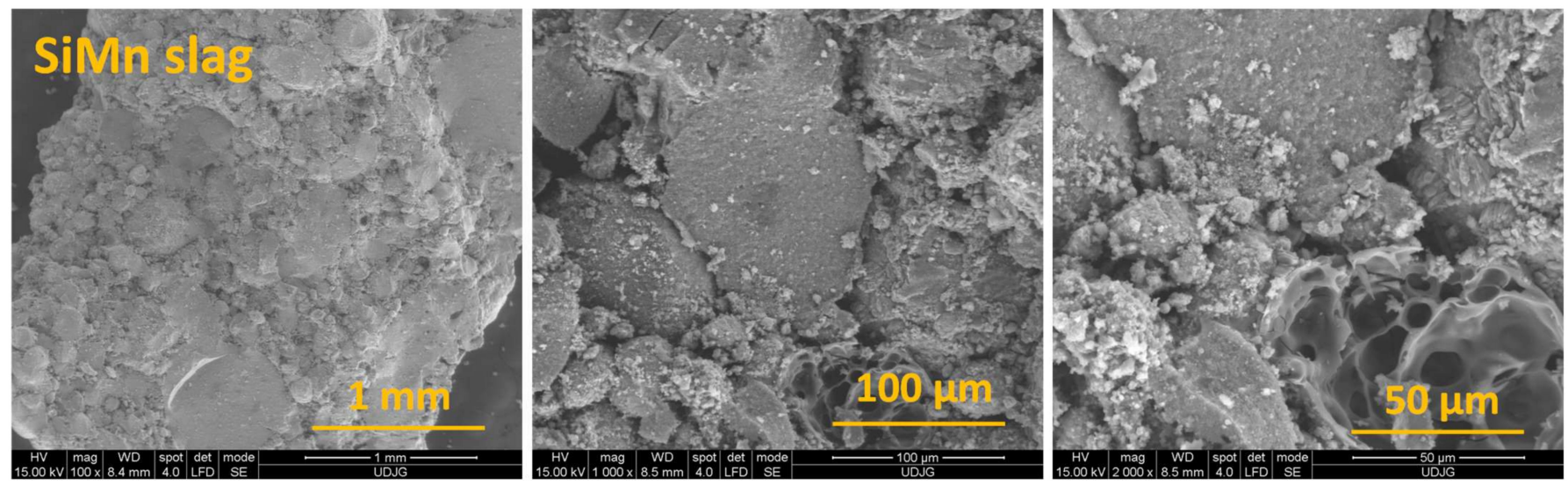

Figure 2. SEM images of silicomanganese slag.

In Figure 3 is shown 3D images of the investigated silicomanganese slag sample. 


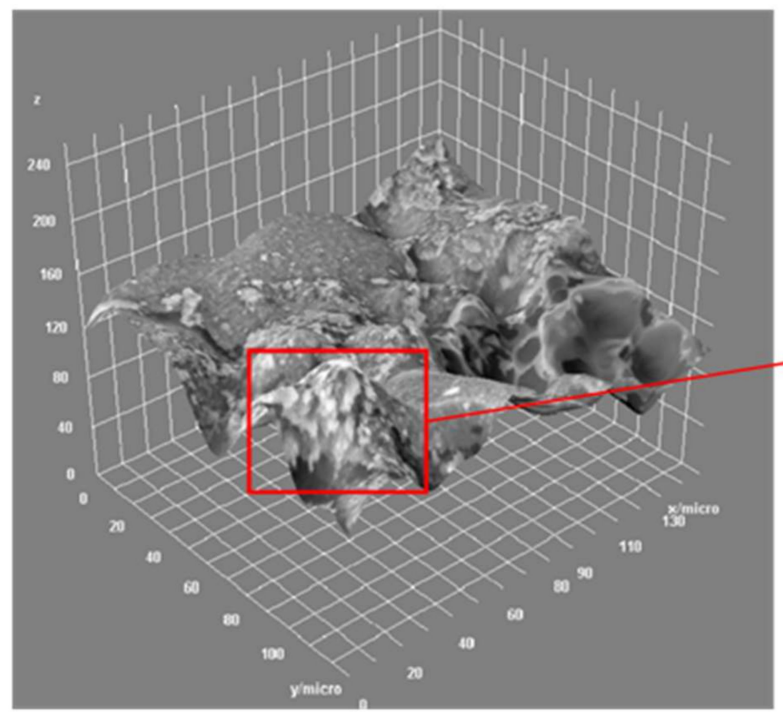

(a)

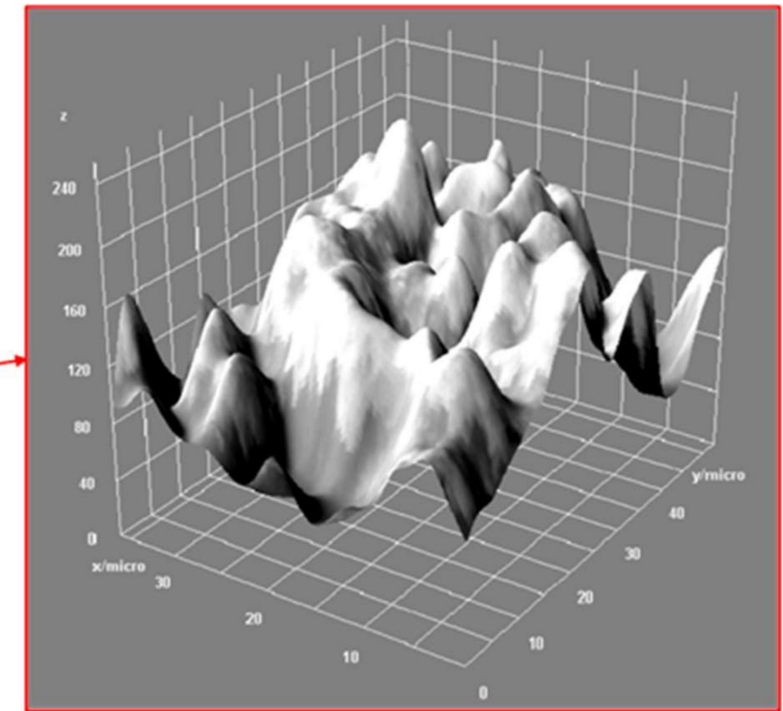

(b)

Figure 3. SEM Images at $10 \mu \mathrm{m}$ (a) and detail (b) of SiMn slag (realized with ImageJ 1.46r software).

ImageJ software highlighted the roughness of the slag sample and as we can see from the Figure 3 all the particles have rough surfaces and edges. In addition, crater-like bodies were seen and the structures similar to rods with length values between 4.83 and $11.07 \mu \mathrm{m}$. The size of the different structure particles ranges from $2.01 \mu \mathrm{m}$ to $5.41 \mu \mathrm{m}$, but, at the same time, we can observe that there are agglomerates of particles shown in the detailed section with the red line (Figure 3). So, from the observations made, the SEM images show smooth aggregates coated by nanoparticles.

The EDX spectra and elemental analysis of the investigated sample are presented in Figures 4 and 5. As can be seen from the EDX spectra, the main elements composing the SiMn slag were carbon, oxygen, calcium, manganese, silicon, aluminum and iron.

Figure 4 shows the EDX spectra of the SiMn slag recorded on different selected punctual areas in order to obtain more information about the elemental composition of specific areas. In the case of point 1 with a spheric structure, the values of the chemical elements are bigger than the other two rod-like structures (Point 2) and smooth areas (Point 3). In addition, a significant increase in the Ca content at Point 2 can be seen.
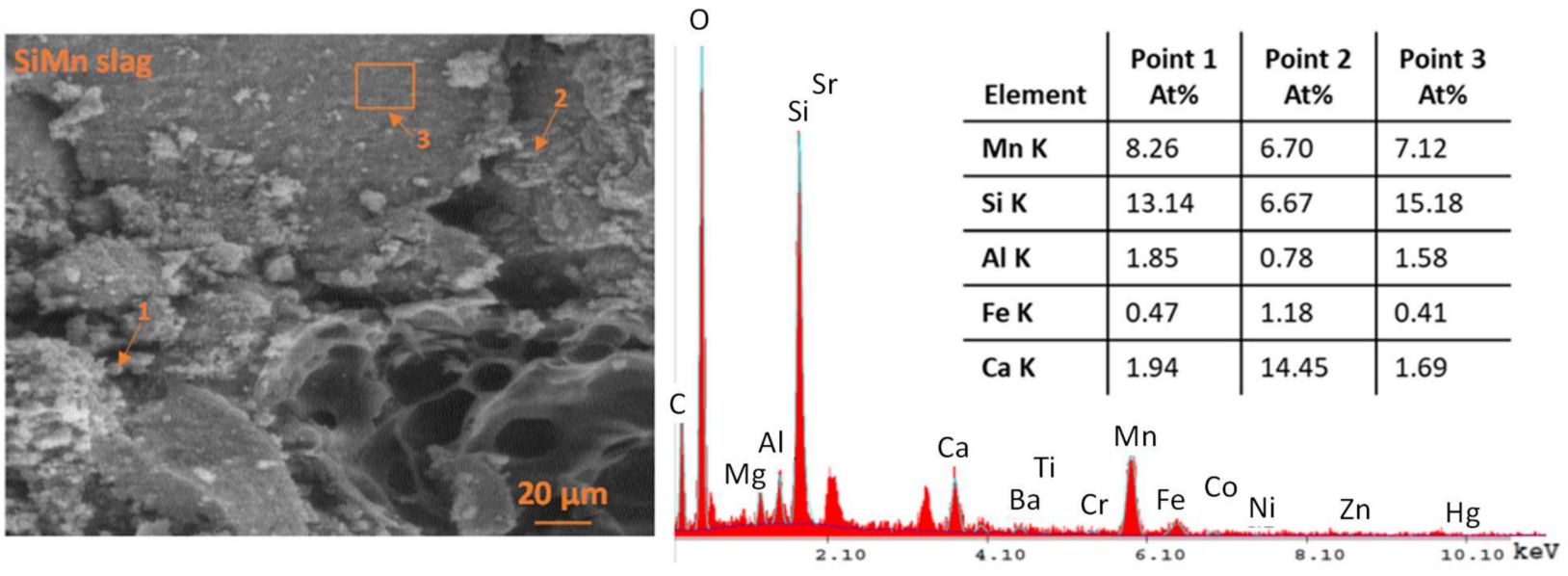

Figure 4. EDX spectra analysis of SiMn slag. 


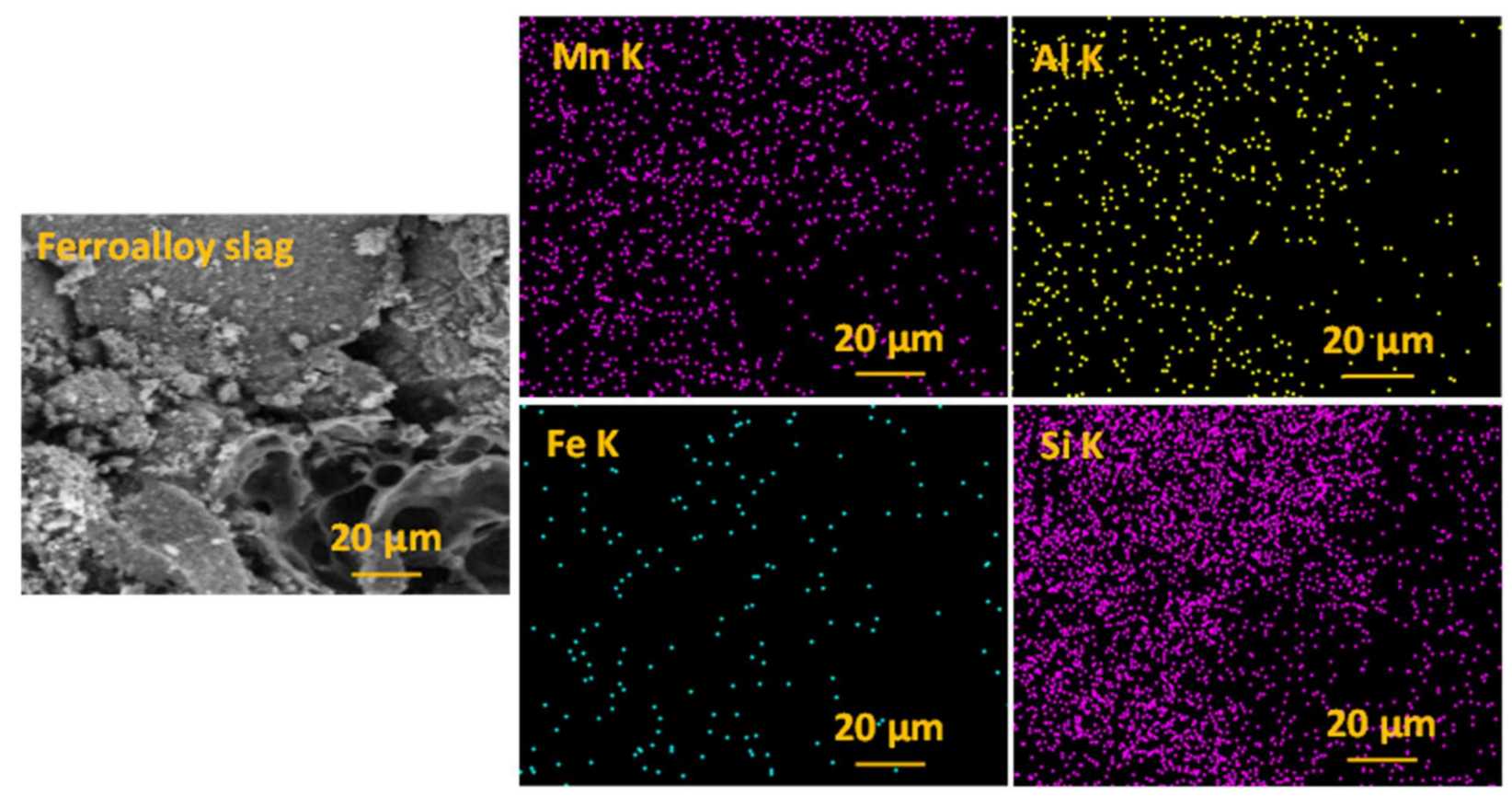

Figure 5. EDX elemental map of silicomanganese slag.

The surface distribution using the EDX analysis (Figure 5) shows the composition of the particles, as well as the distribution of the elements in the examined area.

One can notice from the elemental composition that there are some organic structures (formed during landfilling) with pores in the range of 4.92 to $16.34 \mu \mathrm{m}$. From the SEM images and the associated EDX elemental maps, one can observe a correlation between the increased concentration in the above-mentioned chemical elements and the morphological structures.

The percent ( $w t \%)$ of chemical elements resulted from XRF analysis (Table 1) was different depending on size particles. Table 1 illustrates that at both size fractions of initial slag are not significant differences at percent of the presented chemical elements. The XRF analysis highlighted that the type of obtained slag from the ferro-alloy plant Tulcea is based on silicon-manganese. At a size fraction of slag $<80 \mu \mathrm{m}$, a variation can be observed in the percentage of silicon at different phases of slag, but we cannot say the same thing in the case of size fraction of 80 to $315 \mu \mathrm{m}$.

Table 1. Chemical composition determined with XRF (wt \%) of different phases of the slag.

\begin{tabular}{ccccccc}
\hline \multirow{2}{*}{ Element } & \multicolumn{3}{c}{$\mathbf{8 0} \boldsymbol{\mu \mathrm { m }}$} & \multicolumn{3}{c}{$\mathbf{3 1 5} \boldsymbol{\mu m}$} \\
\cline { 2 - 7 } & Initial & Calcinated & Leached & Initial & Calcinated & Leached \\
\hline $\mathrm{Mn}$ & 67.10 & 74.55 & 44.10 & 67.58 & 68.88 & 53.46 \\
\hline $\mathrm{Si}$ & 25.64 & 18.39 & 37.70 & 25.20 & 16.06 & 25.11 \\
\hline $\mathrm{Fe}$ & 4.19 & 5.08 & 15.14 & 4.30 & 10.96 & 19.38 \\
\hline $\mathrm{Zn}$ & 1.37 & 1.62 & 0.59 & 1.15 & 3.31 & 1.06 \\
\hline $\mathrm{Zr}$ & 0.13 & 0.11 & 0.15 & 0.12 & 0.13 & 0.12 \\
\hline Others & 1.57 & 0.25 & 2.85 & 1.65 & 0.66 & 0.87 \\
\hline
\end{tabular}

From the results illustrated in Table 1, the percentages of manganese (main element) at different phases of slag were highlighted in Figure 6. In the case of granulated slag at size fraction $<80 \mu \mathrm{m}$, an increase in the manganese concentration from $67.10 \%$ to $74.55 \%$ was observed after the calcinated procedure. On the other side, for the size fraction 80 to $315 \mu \mathrm{m}$, the proportion of manganese has a small increase from $67.58 \%$ to $68.88 \%$. The 
results regarding manganese proportion shows that the correlation between size particles and surface area of the reducing particles is confirmed by high temperature of calcination at about $1474 \mathrm{~K}$. We consider that the part of manganese passed in leaching solution is an advantage due to the fact that it can be introduced in the metallurgical process saving natural manganese resources used as raw material.

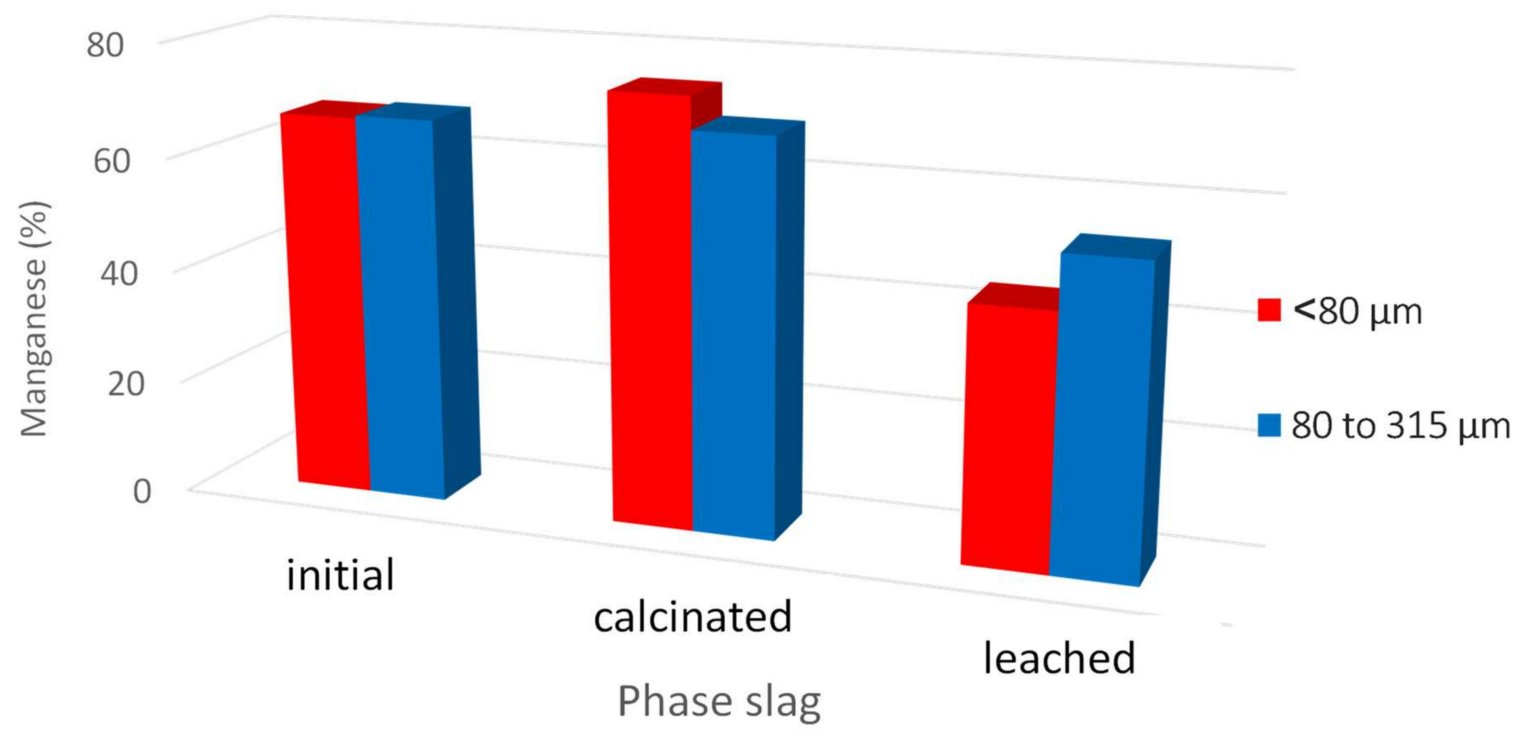

Figure 6. Manganese percentage on the different phases of the slag.

Overall, based on the results obtained in our study, we can affirm that the chosen method to recover manganese is satisfying even if the manganese percent is small comparative with its environmental impact damages. Though verry little data are available on this research area, we should monitor the evolution of slag dump and improve the leaching process in future studies.

\section{Conclusions}

This investigative study of the landfilled slag area demonstrated that the leaching process of dumped slag is satisfying in the prevention of environmental pollution. The motivation of our study is to confirm that exist the possibility to recover manganese from slag, and the remaining fraction is used as aggregate sources in order to decommission the slag dump. On the other hand, the proposed research is in concordance with the sustainable use of natural resources for the achievement of the sustainable development of the 2030 Agenda. Even if the proposed method is expensive, but to comply with the objectives of the European Directives and Waste Management Legislation, the environmental costs are huge on non-conforming waste dumping. If we consider the cost-benefit analysis of environmental future, it is more important human health and the benefits on the quality of the population's health and the environment, which are not not measured in monetary value.

The results from this study, together with large-scale environmental issues, pose significant implications for further studies, which consist of finding different ways to extract manganese from leaching solution and to introduce it into the metallurgical process in order to save natural manganese resources.

Author Contributions: Conceptualization and methodology, D.L.B. and V.G.; software, C.-D.O.; investigation, E.E.H.; writing-original draft preparation, D.L.B. and V.G. All authors have read and agreed to the published version of the manuscript.

Funding: This research received no external funding.

Institutional Review Board Statement: Not applicable. 
Informed Consent Statement: Not applicable.

Acknowledgments: This research was supported by the project "ANTREPRENORDOC", Contract no. 36355/23.05.2019, financed by the Human Capital Operational Programme 2014-2020 (POCU), Romania.

Conflicts of Interest: The authors declare no conflict of interest.

\section{References}

1. Mavroudis, I.; Petrides, F.; Karantali, E.; Chatzikonstantinou, S.; McKenna, J.; Ciobica, A.; Iordache, A.-C.; Dobrin, R.; Trus, C.; Kazis, D. A voxel-wise meta-analysis on the cerebellum in essential tremor. Med. Lith. 2021, 57, 264.

2. Statescu, C.; Honceriu, C.; Jurcau, R.N.; Trus, C. An Original Study on the Correlations Between Magnesium and Depression and their Cardiovascular Relevance. Rev. Chim. 2019, 70, 4102-4104. [CrossRef]

3. Statescu, C.; Honceriu, C.; Trus, C. Does Magnesium Deficient Diet and its Associated Metabolic Dysfunctions Induces Anxietylike Symptoms Further cardiovascular relevance. Rev. Chim. 2019, 70, 3579-3581. [CrossRef]

4. Das, B.; Prakash, S.; Reddy, P.S.R.; Misra, V.N. An overview of utilization of slag and sludge from steel industries. Resour. Conserv. Recycl. 2007, 50, 40-57. [CrossRef]

5. Ayala, J.; Fernandez, B. Recovery of manganese from silicomanganese slag by means of a hydrometallurgical process. Hydrometallurgy 2015, 158, 68-73. [CrossRef]

6. Huaiwei, Z.; Hong, X. An overview for the utilization of wastes from stainless steel industries. Resour. Conserv. Recycl. 2011, 55, 745-754. [CrossRef]

7. Koros, P.J. Dusts, scale, slags, sludges. Not wastes, but sources of profits. Metall. Mater. Trans. B 2003, 34, 769-779. [CrossRef]

8. Faisal, A.A.H.; Alquzweeni, S.S.; Naji, L.A.; Naushad, M. Predominant Mechanisms in the Treatment of Wastewater Due to Interaction of Benzaldehyde and Iron Slag Byproduct. Int. J. Environ. Res. Pub. Health 2020, 17, 226. [CrossRef]

9. Santamaria, A.; Gonzalez, J.J.; Losanez, M.M.; Skaf, M.; Ortega-Lopez, V. The design of self-compacting structural mortar containing steelmaking slags as aggregate. Cem. Concr. Comp 2020, 111, 103627. [CrossRef]

10. Qasrawi, H. The use of steel slag aggregate to enhance the mechanical properties of recycled aggregate concrete and retain the environment. Constr. Build Mater. 2014, 54, 298-304. [CrossRef]

11. Desa, U.N. Transforming Our World: The 2030 Agenda for Sustainable Development; United Nations: Geneva, Switzerland, 2015; p. 15-16301 (E). Available online: https:/ /sdgs.un.org/2030agenda (accessed on 30 August 2021).

12. Buruiana, D.L.; Bordei, M. Industrial waste recovery solutions for rehabilitation of affected. Metal. Int. 2011, 16, 155-158.

13. Buruiana, D.L.; Lefter, D.; Tiron, G.L.; Balta, S.; Bordei, M. The influence on the environment factors of waste disposal in undeveloped areas. Int. Multi. Sci. Geoco. 2015, 2, 573-579.

14. Buruiana, D.L.; Lefter, D.; Tiron, G.L.; Balta, S.; Bordei, M. Toxicity of heavy metals on the environment and human health. Int. Multi. Sci. Geoco. 2015, 27, 565-571.

15. Buruiana, D.L.; Balta, S.; Iticescu, C.; Georgescu, L.P.; Humeniuc, I.I. Determining the concentration of heavy metals in the soils near slag landfills. Rev. Rom. Mat. 2016, 46, 108-114.

16. Shelburne, W.M.; Degroot, D.J. The use of waste \& recycled materials in highway construction. Civ. Eng. Pract. 1998, 13, 5-16.

17. Groot, D.R.; Kazad, D.M.; Pollmann, H.; Villiers, J.P.R.; Redtmann, T.; Steenkamp, J. The recovery of manganese and generation of a valuable residue from ferromanganese slags by hydrometallurgical route. In Proceedings of the Thirteenth International Ferroalloys Congress, Efficient Technologies in Ferroalloy Industry, Almaty, Kazakhstan, 9-13 June 2013; pp. 1051-1060.

18. Sully, A.H. Metallurgy of the Rarer Metals Manganese; Butterworths Scientific Publications: London, UK, 1955; pp. 7-10.

19. Urane, D. Process for the Manufacture of Ferromanganese. Australian Patent US3433628A, 18 March 1969.

20. Kim, B.-S.; Jeong, S.-B.; Jeong, M.-H.; Ryu, J.-W. Upgrading of manganese from waste silicomanganese slag by a mechanical separation process. Mater. Trans. 2011, 135-923. [CrossRef]

21. Aleksandrov, A.A.; Dashevskii, V.Y.; Leontev, L.I. Manganese extraction from slag obtained in the production of refined manganese ferroalloys. Steel Transl. 2013, 43, 661-665. [CrossRef]

22. Naganoor, P.C.; Prasanna, A.S.R.; Shivaprasad, K.H.; Bhat, K.L. Extraction of manganese from Ferro-manganese slag. Process. Fines 2000, 2, 300-306.

23. Bodor, M.; Balta, S.; Pintilie, S.C.; Lazar, A.L.; Buruiana, D. Studies regarding the distribution and composition of particulate matters in the air of an industrialized city. Int. Multi. Sci. Geoco. 2016, 2, 587-592.

24. ICPDR, 2019, International Commission for the Protection of the Danube River. Flyer Reprint. Available online: https://www. icpdr.org/main/icpdr/danube-river-protection-convention (accessed on 28 August 2021).

25. Murariu, G.; Iticescu, C.; Murariu, A.; Rosu, B.; Munteanu, D.; Buruiana, D.L. Assessment of Water Quality State Dynamics Using Adaptive Filtering Methods and Neural Networks Approaching Case study-Danube River in Galati area. Rev. Chim. 2019, 70, 1914-1919. [CrossRef]

26. Buruiana, D.L. Economic impact analysis of the possibility to recycle wastes from ship building. Int. Multi. Sci. Geoco. 2012, 4, 685-692.

27. Haider, F.U.; Liqun, C.; Coulter, J.A.; Cheema, S.A.; Wu, J.; Zhang, R.; Wenjun, M.; Farooq, M. Cadmium toxicity in plants: Impacts and remediation strategies. Ecotox. Environ. Saf. 2021, 211, 111887. [CrossRef] [PubMed] 
28. Peel, J.L.; Richard, H.; Valerie, G.; Armistead, G.R.; Lucas, N. Impact of Nitrogen and Climate Change Interactions on Ambient Air Pollution and Human Health. Biogeochemistry 2013, 114, 121-123. [CrossRef]

29. Petrescu, T. Report on the Environmental Impact Study. 2009. Available online: https://www.eib.org/attachments/pipeline/20 110247_eia_ro.pdf (accessed on 1 September 2021).

30. Makedonski, L.; Peycheva, K.; Stancheva, M. Determination of heavy metals in selected black sea fish species. Food Contr. 2017, 72, 313-318. [CrossRef]

31. Simionov, I.-A.; Cristea, D.S.; Petrea, S.-M.; Mogodan, A.; Nicoara, M.; Plavan, G.; Baltag, E.S.; Jijie, R.; Strungaru, S.-A. Preliminary investigation of lower Danube pollution caused by potentially toxic metals. Chemosphere 2021, 264, 128496. [CrossRef] [PubMed]

32. Strungaru, S.-A.; Nicoara, M.; Teodosiu, C.; Baltag, E.; Ciobanu, C.; Plavan, G. Patterns of toxic metals bioaccumulation in a cross-border freshwater reservoir. Chemosphere 2018, 207, 192-202. [CrossRef] 